\title{
The legacy of fire: long-term changes to the forest understory from periodic burns in a New England oak-hickory forest
}

\author{
Caroline G. Borden ${ }^{1 *}$ D, Marlyse C. Duguid ${ }^{2}$ and Mark S. Ashton ${ }^{2}$
}

\begin{abstract}
Background: Over the last century, fire exclusion has caused dramatic structural and compositional changes to southern New England forests, highlighting the need to reintroduce fires into the historically pyrogenic landscape to study the response. We investigated the effects of a single overstory thinning and midstory removal to create an open oak-hickory woodland structure, followed by repeated prescribed burns. We hypothesized that burning would create greater floristic diversity comprising fire-tolerant woody regeneration and shade-intolerant herbaceous flora. We followed shifts in plant structure, composition, and diversity over a 23-year period, using a before-after-controlimpact design with data collected once prior to burning and twice after burn treatments had begun and with soil samples collected after nearly 20 years of burning.

Results: We observed a dense ingrowth of saplings on unburned plots that were largely absent from burned plots and a shift in midstory composition to favor mesic sweet birch (Betula lenta L.) in the unburned treatment, as opposed to the hickories (Carya Nutt. spp.) and oaks (Quercus L. spp.) that dominated the burned treatment. Burning resulted in a significantly greater density, richness, Shannon diversity, and evenness of understory vegetation (forbs, shrubs, tree seedlings). These four measures remained high on burned plots, despite a decrease in both floristic diversity and evenness on unburned plots and a reduction in unburned site-level richness. Understory composition varied significantly by year and burn treatment, with unburned plots largely characterized by shade-tolerant species while burned plots showed an enhanced abundance of heliophilic plants.
\end{abstract}

Conclusions: Our results suggest that periodic burning increases nutrient microsite heterogeneity and periodically maintains greater understory light, both of which in turn increase understory plant density and diversity and cause a shift in understory composition. This study shows that repeated prescribed burns in an open New England woodland have lasting structural and compositional effects capable of restoring pre-settlement, pyrogenic vegetation patterns.

Keywords: BACl, Carya, Diversity, Forbs, Prescribed burning, Quercus, Savanna woodland, Soil nutrients, Species composition, Species richness

\footnotetext{
* Correspondence: caroline.borden@aya.yale.edu

${ }^{1}$ Department of Ecology \& Evolutionary Biology, Yale University, 165 Prospect

St, New Haven, CT 06511, USA

Full list of author information is available at the end of the article
}

\section{Springer Open}

(c) The Author(s). 2021 Open Access This article is licensed under a Creative Commons Attribution 4.0 International License, which permits use, sharing, adaptation, distribution and reproduction in any medium or format, as long as you give appropriate credit to the original author(s) and the source, provide a link to the Creative Commons licence, and indicate if changes were made. The images or other third party material in this article are included in the article's Creative Commons licence, unless indicated otherwise in a credit line to the material. If material is not included in the article's Creative Commons licence and your intended use is not permitted by statutory regulation or exceeds the permitted use, you will need to obtain permission directly from the copyright holder. To view a copy of this licence, visit http://creativecommons.org/licenses/by/4.0/. 


\section{Resumen}

Antecedentes: Durante la última centuria, la exclusión del fuego ha causado cambios dramáticos en la estructura y composición en los bosques del sur de Nueva Inglaterra, subrayando la necesidad de reintroducir los fuegos en ese paisaje históricamente pirógeno para estudiar su respuesta. Investigamos los efectos de un único raleo de copas y remoción del estrato medio para crear un bosque de estructura abierta de roble-nogal, seguido de repetidas quemas prescriptas. Hipotetizamos que las quemas podrían crear una mayor diversidad florística que comprenda una regeneración de leñosas tolerantes al fuego y una flora intolerante a la sombra. Seguimos los cambios en la estructura de las plantas, composición y diversidad por un período de treinta y tres años, usando un diseño de control de impactos antes post tratamientos, con datos colectados una vez previo a la quema y dos veces luego de comenzado el tratamiento, y con muestras de suelo colectadas casi veinte años después de las quemas.

Resultados: Observamos un denso crecimiento de plántulas en parcelas no quemadas que estuvieron ausentes en las parcelas quemadas, y un cambio en la composición del estrato medio que favoreció al abedul dulce (Betula lenta L.) en el tratamiento no quemado, en oposición a los nogales (Carya Nutt. spp.) y robes (Quercus L. spp.), que dominaron en el tratamiento quemado. El tratamiento quemado resultó en una mayor densidad. riqueza, diversidad de Shannon y equitatividad en la vegetación del sotobosque (hierbas, arbustos, y plántulas de árboles). Estas cuatro medidas permanecieron altas en las parcelas quemadas, a pesar del decrecimiento tanto en diversidad florística y equitatividad en las parcelas no quemadas y en la reducción de la riqueza a nivel de sitio en parcelas no quemadas. La vegetación del sotobosque varió significativamente en función de los años y del tratamiento de quema, con las parcelas no quemadas largamente caracterizadas por especies tolerantes a la sombra mientras que las parcelas quemadas mostraron una mayor abundancia de especies heliófilas.

Conclusiones: Nuestros resultados sugieren que las quemas periódicas incrementan la heterogeneidad de los nutrientes en los micrositios y mantienen periódicamente mayor luz en el sotobosque, ambos incrementando en el tiempo la densidad y diversidad de plantas y causando cambios en la composición del sotobosque. Este estudio muestra que quemas prescriptas repetidas en un bosque abierto de Nueva Inglaterra tienen efectos estructurales y composicionales duraderos capaces de restaurar los patrones pirógenos de la vegetación anteriores a la colonización.

\section{Background}

This last century has seen the suppression of the dominant fire regime of the original oak-hickory forests of the northeastern United States, resulting in dramatic vegetation shifts across the landscape. Prior to European settlement, much of the upland skeletal glacial till soil and sand plains of major southern New England valleys comprised open woodlands characterized by low-intensity fires at infrequent intervals of 10-20 years (Patterson and Sassaman 1988; Patterson 2006; Guyette et al. 2012; Cronon 2011; Poulos 2015). Causes of these periodic fires include lightning ignitions, Indigenous land management practices, and European colonial settlement, the latter of which caused a temporary spike in fire frequency (Patterson and Sassaman 1988; Fuller et al. 1998; Poulos 2015; Stambaugh et al. 2015; Abrams and Nowacki 2020). These surface fires played a role in shaping the vegetative composition of the forests and woodlands of the northeastern United States by promoting fire-adapted, shade-intolerant species such as oaks (Quercus L. spp.), hickories (Carya Nutt. spp.), and pines (Pinus L. spp.) (Foster et al. 1998, 2002; Fuller et al. 1998; Nowacki and Abrams 2008).
However, the imposition of fire-suppression policies in the early 1900 s removed fire as an ecological driver from the New England landscape, resulting in dramatic vegetation shifts (Brose et al. 2001, 2014; Hall et al. 2002; Nowacki and Abrams 2008; Poulos 2015). As expected from the pre-settlement association between frequent fires and low tree density, modern forest stands are substantially denser than pre-settlement conditions (Brose et al. 2001; Hall et al. 2002; Nowacki and Abrams 2008; Ryan et al. 2013). On a macro scale, this has translated to a rapid shift from open savannas and woodlands to closed canopy forests that corresponds closely with the decline of fires on the landscape (Patterson and Sassaman 1988; Brose et al. 2001; Nowacki and Abrams 2008; Cronon 2011). Numerous studies have documented this structural change triggering a positive feedback cycle dubbed "mesophication," whereby microenvironmental conditions under dense forest canopies favor shadetolerant, mesic species such as maple (Acer L. spp.), cherry (Prunus L. spp.), and birch (Betula L. spp.) over the shade-intolerant, fire-adapted species such as oak, hickory, and pine that used to dominate this landscape (Brose et al. 2001; Hall et al. 2002; Nowacki and Abrams 2008; Kreye et al. 2013; Poulos 2015). The impact of this 
mesophication on overall floristic diversity and richness is more nuanced (Anderson and Schwegman 1991; Nowacki and Abrams 2008). Nowacki and Abrams (2008) found an increase in tree diversity, which they attributed to the transitional stage that hosts a combination of arriving fire-sensitive and relict fire-resistant species. With further fire exclusion, it is possible that diversity could decline due to increased canopy shade and the progressive dominance of fire-sensitive, shade-tolerant species, as has already been observed by Anderson and Schwegman (1991) (Ryan et al. 2013; Stambaugh et al. 2015).

Numerous studies have attempted to better understand the historic effect of fires by re-introducing fire to the landscape; however, existing research on prescribed burns in oak-hickory forests has generally been limited to the southeast and midwest regions of the USA (Hart and Buchanan 2012; Brose et al. 2014; Varner et al. 2016). Indeed, a 2014 review of fire effect studies in oak systems found that only 2 of 58 papers pertained to studies conducted in New England (Brose et al. 2014). The few fire studies that have been conducted in Connecticut are limited in scope; most investigate the impact of a single burn and focus exclusively on trees, leaving the long-term effects on understory and soils largely unstudied (Ward and Stevens 1989; Ducey et al. 1996; Ward and Brose 2004).

This remains a significant gap, as the existing studies outside of New England reveal that the effects of repeated burns on oak-hickory ecosystems vary greatly by region; within oak-hickory ecosystems, different studies have revealed that burning can result in an increase or decrease in understory richness, diversity, and density depending on the site (Elliott et al. 1999; Hutchinson and Sutherland 2000; Kinkead et al. 2013; Lettow et al. 2014). Longer timeframes with repeated burns add to this complexity; different frequencies of burn treatments can elicit varied responses in forest structure and composition, and the vegetative response to a single burn is often not indicative of the long-term response to subsequent burns (DeSelm and Clebsch 1991; Peterson and Reich 2001; Dey and Fan 2009; Knapp et al. 2015). Research on the impact of fires on soil is likewise mixed; when fire-induced changes in soil properties occur, they are often short-lived and show substantial variation both within an ecosystem and between ecosystems (Certini 2005; Gundale et al. 2005; Boerner et al. 2009; Ganzlin et al. 2016).

As in most ecosystems, the overstory, understory, and soil properties of a New England forest are intimately related, as soil nutrient limitation often regulates the productivity and diversity of higher trophic levels, overstory shading drives understory compositional changes, and both overstory and understory vegetation can in turn regulate nutrient fluxes in the soil (Chapin et al. 1986;
Ducey et al. 1996; Ellum 2009; Lettow et al. 2014). However, no studies integrating vegetation and soil data over long time scales with repeated burns exist in southern New England oak-hickory ecosystems, with the result that the long-term impact of repeated prescribed burns in this region remains unstudied and the resulting management guidance remains unavailable.

In this study, we investigate the effect of overstory cutting followed by repeated prescribed burns on a southern New England oak-hickory ecosystem over a 23-year period. Using a before-after-impact-control design, we bring together data on forest structure, soil characteristics, and vegetation to investigate fire-induced changes in understory density, diversity, and composition and to determine how these changes are influenced by structural shifts in the overstory and soil properties following prescribed burns. By introducing periodic, low-intensity burns into an established oak-hickory forest, we attempt to mimic pre-settlement conditions and to better understand the effects of restoring the historical southern New England fire regime (Patterson and Sassaman 1988; Parshall and Foster 2002; Ruffner 2006; Poulos 2015; Abrams and Nowacki 2020).

\section{Methods \\ Study site}

We conducted our research at the Yale-Myers Research and Demonstration Forest, belonging to Yale University. The forest comprises 3213 ha and is located in northeastern Connecticut, USA, $41.95^{\circ} \mathrm{N}, 72.14^{\circ} \mathrm{W}$ (Fig. 1a). The forest consists of ridge and valley topography underlain by ancient metamorphic bedrock, but the soils are relatively young, classified as inceptisols of glacial till origin (Soil Survey Staff 1999). Differences in elevation ranges from 170 to $300 \mathrm{~m}$ above sea level. Average temperatures are $21.3^{\circ} \mathrm{C}$ in July and $-4.4{ }^{\circ} \mathrm{C}$ in January with an approximately equal distribution of precipitation throughout the year totaling about $1270 \mathrm{~mm}$ (NOAA 2020). The forest type would be considered in a transition zone between northern hardwoods and oak-hickory forest (Cogbill et al. 2002; Fralish 2003; Lefland et al. 2018).

We conducted our experiment on a 2-ha oak savanna woodland. Located on well-drained glacial tills comprising Charlton-Hollis fine sandy loams, the site comprised a second growth oak hickory stand that grew in on two adjacent enclosed pastures associated with a subsistence homestead that was abandoned in 1915 (NRCS 2008). Prior to 1915, the field was repeatedly burned by the farmer to clear the encroaching shrubs and trees; thereafter, succession proceeded to dominance by firetolerant oaks and hickories. The stand has been protected from fire since 1930 and underwent a commercial crown thinning in the 1970s, resulting in a basal area of $30 \mathrm{~m}^{2} \mathrm{ha}^{-1}$ by 1996 . In 1996, we thinned the stand to 


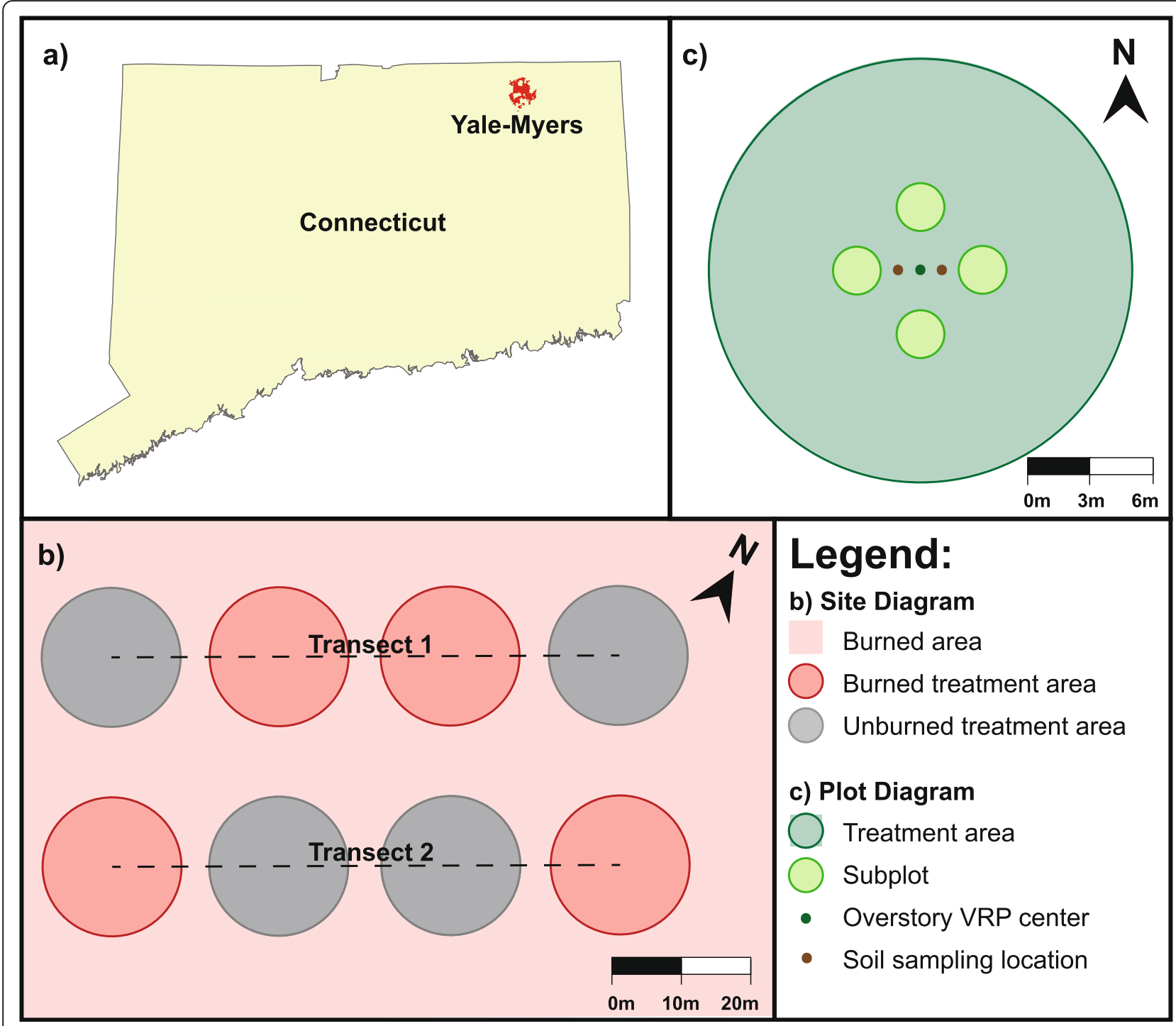

Fig. 1 a Location map of Yale-Myers Research and Demonstration Forest in northeastern Connecticut (Yale School Forests 2019; Utah AGRC 2020). b Diagram of the study site showing eight treatment areas laid out along two transects, identified as burned or unburned. c Close-up diagram of a single treatment area with sampling locations for overstory, understory, and soil data collection marked

create the structure of a savanna by removing all of the subcanopy and spacing the residual overstory oak and hickory trees about $15 \mathrm{~m}$ apart with a residual basal area of about $7 \mathrm{~m}^{2} \mathrm{ha}^{-1}$. No herbicide was applied, as the trees that were cut have a poor capacity to sprout. Those that did sprout did so weakly and were subsequently knocked back by the repeated burning.

\section{Experimental design}

We aligned two transects along the length of each former field, parallel to the stone wall separating the fields, and selected the start of each transect randomly using a 10-m buffer to avoid the edge effects of the walls and edges of the fields. Along these two transects, we established eight 10-m-radius treatment areas, four of which were randomly designated to be burned and the other four to be held as unburned controls (Fig. 1b). The center point of each of these treatment areas served as the center point for the overstory variable radius plot (VRP). We placed four circular 1.13-m-radius understory measurement subplots $\left(4-\mathrm{m}^{2}\right.$ area) with their centers $3 \mathrm{~m}$ from the center of each treatment area along the cardinal directions (north, south, east, and west) for a total of 32 subplots (Fig. 1c).

We implemented prescribed burns on the entire study area, excluding the four fire exclusion treatment areas, in April 2003, April 2006, and April 2012, which was prior to bud break and the emergence of most herbaceous plants, while the ground was wet and cold (Fig. 2). The burns were low-intensity surface fires with average flame lengths 


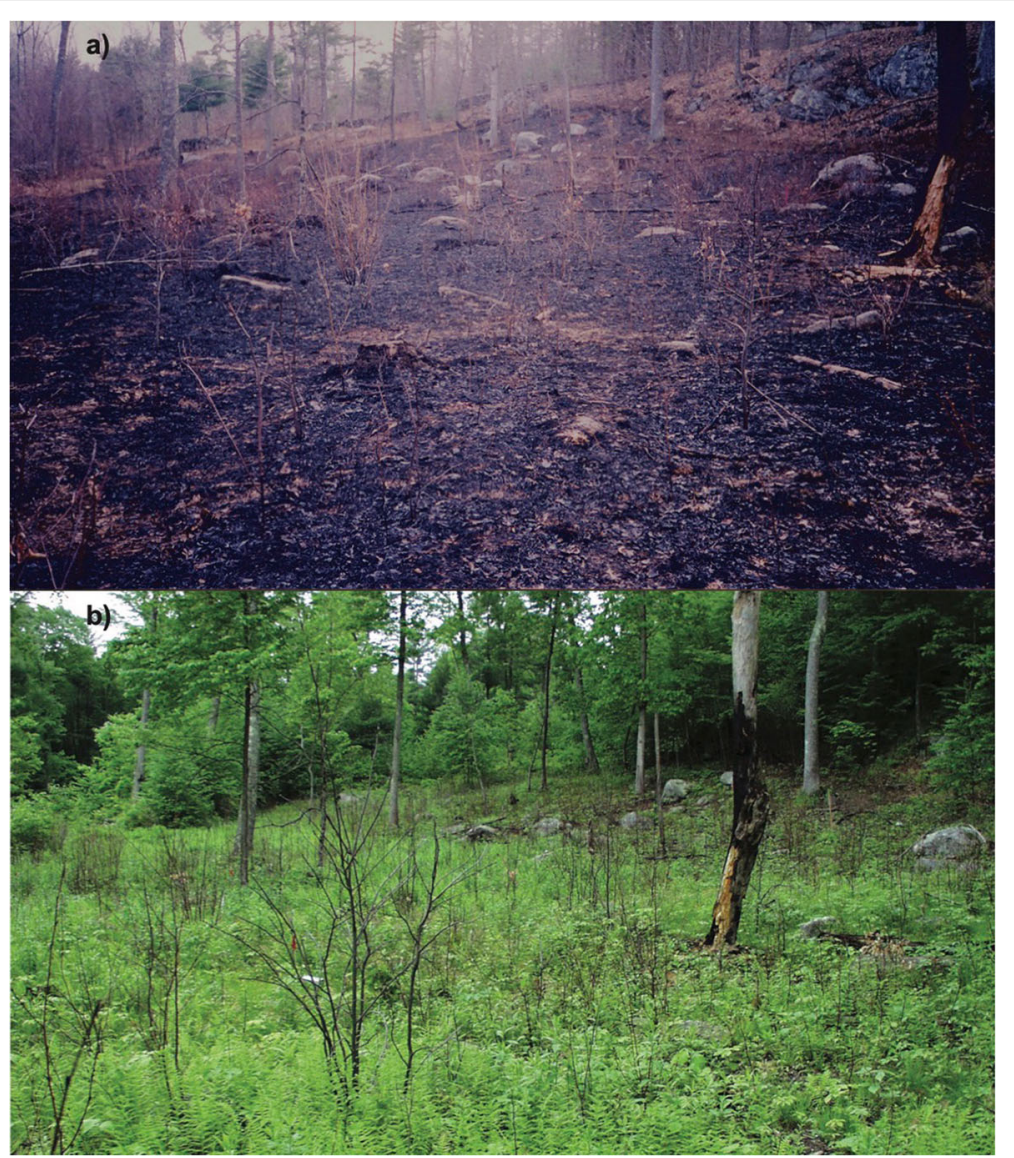

Fig. 2 Photos of the study site in the Yale-Myers Research and Demonstration Forest, Eastford, CT, USA, in a April 2003, immediately post-burn, and $\mathbf{b}$ June 2003, after 2 months of regrowth following the 2003 prescribed burn

of 0.3 to $0.6 \mathrm{~m}$ or less. The fuel was predominantly thatch from grasses and ferns that had died the previous winter, and overstory mortality largely occurred in saplings and poles of thin-barked, fire-sensitive black birch up to $10-\mathrm{cm}$ diameter-at-breast height (DBH, $1.3 \mathrm{~m})$. We collected vegetation data on three separate occasions: in August 1996, prior to the 1996 thinning treatment and any burn treatments, in July 2006, and in July 2019. We collected soil samples in July 2019 after over 20 years of treatment.

For overstory measurements at each of the eight plots, we measured DBH for all "in" trees using variable radius point sampling with an angle gauge (Basal Area Factor 10, English). We collected understory floristic data for all 32 subplots. We identified each understory plant to the species level, with the exception of the genera grape (Vitis L. spp.), hawkweed (Hieracium L. spp.), hawthorn (Crataegus L. spp.), serviceberry (Amelanchier Medik. spp.), and hickory, which we identified to the genus level. To measure abundance, we recorded individual stem counts for forbs and woody plants (i.e., shrubs, tree seedlings), and for species with clonal growth forms (i.e., ferns, graminoids) where stem counts were not possible, we recorded percent cover to the nearest 1\%. In 2019, we took measurements to estimate canopy cover above each of the 32 subplots using a Forestry Suppliers Spherical Crown Densiometer concave model C. We calculated percentage canopy cover for each subplot by multiplying the raw densiometer score, which represented the number of the 96 equally spaced points encompassed by overstory trees, by 1.04 .

In 2019, we collected several soil cores $(2.5-\mathrm{cm}$ diameter) from $1 \mathrm{~m}$ east and $1 \mathrm{~m}$ west of the center point of each of the eight treatment areas, using the top $10 \mathrm{~cm}$ of mineral soil for chemical analysis (Fig. 1c). We air dried all samples and passed them through a $2-\mathrm{mm}$ sieve. We ground a small subset of each sample in a ball mill and sent the samples to the Yale Analytical and Stable Isotope Facility, New Haven, Connecticut, USA, where we conducted \% $\mathrm{C}$ and \% $\mathrm{N}$ analysis using an elemental analyzer (Costech ESC 4010, Valencia, CA, USA). We sent the remainder of each sample to the UMASS Soil and Plant Nutrient Testing Laboratory, Amherst, MA, USA, for further analysis. Phosphorus, potassium, calcium, magnesium, and aluminum were determined using 
an inductively coupled plasma spectrograph, and $\mathrm{pH}$ was determined by a LabFit AS-3000 pH analyzer.

\section{Data analysis}

Since all 1996 vegetation data were collected prior to any burn treatments, we pooled 1996 data for many of our analyses. When a distinction is made, the subplots designated to be held as unburned controls are referred to as "pre-unburned," while the subplots designated for future burns are referred to as "pre-burned." We focused our analysis of understory floristics on woody plants and forbs. These two functional groups accounted for the vast majority of the abundance and species richness on the site, with ferns (3-10\% cover) and graminoids (9$15 \%$ cover) comprising no more than $7 \%$ and $16 \%$ of species richness, respectively. The grasses and ferns were floristically impoverished, dominated by an upland sedge (Pennsylvania sedge (Carex pensylvanica Lam.)) and two ferns (eastern hayscented fern (Dennstaedtia punctilobula Michx T. Moore), New York fern (Thelypteris noveboracensis L. Nieuwl)). Also, because of the differential growth forms of the functional groups, their corresponding abundance metrics could not easily be combined for analyses. All analyses were conducted in R Studio, Version 3.6.2 (Kindt and Coe 2005; Oksanen et al. 2019; Core Team 2019).

\section{Effects of burning on soil chemistry and overstory forest structure}

To assess overstory compositional shifts over time and across burn treatments, we grouped each overstory tree by genus and visualized relative abundance between years and burn treatment groups. For each overstory plot, we calculated the basal area in $\mathrm{m}^{2} \mathrm{ha}^{-1}$. To assess whether basal area and DBH differed between burned and unburned plots, we ran nonparametric KruskalWallis analysis of variance tests with burn status as the independent variable using overstory data from 2006 and 2019 only. To test whether overstory characteristics differed over time, we ran nonparametric Kruskal-Wallis tests for dependent measures of basal area and $\mathrm{DBH}$ using year as the independent variable. We also used a Kruskal-Wallis test to compare canopy cover over burned subplots to canopy cover over unburned subplots in 2019.

We used normal quantile plots to assess for normality in eight soil properties (soil pH, percent carbon, percent nitrogen, phosphorus, potassium, calcium, magnesium, and aluminum) and log-transformed phosphorus and potassium due to deviations from normality. To test whether soil nutrients differed between burned and unburned treatments, we used a multivariate analysis of variance (MANOVA) model using burn treatment as the independent variable for the eight dependent variables.
To assess the impact of burning on the variance of each of these properties, we used $\mathrm{F}$ tests.

\section{Effects of burning on understory composition}

To depict differences in species composition by year and burn treatment, we generated rank abundance curves of forbs and woody understory species. In addition, we used nonmetric multidimensional scaling (NMDS) to place each subplot on ordination axes generated from Bray-Curtis dissimilarity matrices. Calculations were run from 100 starting locations to find convergent solutions in three dimensions, chosen from scree plots of stress values $(\mathrm{s}<0.2$, final stress $=0.182)$. The dataset used for NMDS combined understory herbaceous and woody counts at the species level from 1996, 2006, and 2019 datasets, excluding any species that appeared on 3 or fewer subplots in a given year and expressing four taxa at the genus level. We fit burn treatment and year to the ordination results and constructed a biplot displaying all subplots. To test whether species composition differed over time, we ran a PERMANOVA model with BrayCurtis distance and 1000 permutations, using the same community dataset as in NMDS, with year as the independent variable. To test whether species composition differed between burned and unburned treatments, we ran a second PERMANOVA model with the same specifications as above, using species counts from the 2006 and 2019 datasets used for NMDS, with burn treatment as the independent variable.

To visualize the associations between taxa and subplots, we used an additional NMDS with the same specifications as above (final stress $=0.147$ ), using 2019 understory counts aggregated at the genus level, again excluding any species that appeared on 3 or fewer subplots. We displayed subplot space and genera from the 2019 understory using the first two ordination axes, with burn treatment and percentage of canopy opening fit to ordination results.

\section{Effects of burning on understory density, richness, diversity, and evenness}

We calculated four additional measures using understory floristics data on a per-subplot $\left(4 \mathrm{~m}^{2}\right)$ scale: (1) the natural log of total plant density, (2) species richness $[S]$, (3) Shannon diversity $\left[H^{\prime}=-\sum_{i=1}^{R} p_{i} \log p_{i}\right]$, and (4) Pielou's Evenness $\left[J^{\prime}=H^{\prime} / \ln S\right.$ ] (Pielou 1966; Magurran 1988). To test whether there were significant differences in these four understory measures between 1996 preburned and pre-unburned subplots, we used a series of two sample $t$ tests (Additional file 1). We used ShapiroWilk tests to confirm normality in these four measures (Additional file 2). To assess whether these understory metrics differed significantly between burn treatments 
and how these effects changed over time, we ran a series of ANOVA models on the dependent variables $\ln (\mathrm{den}$ sity), S, H', and J'. These models were run with subplotlevel data from 2006 and 2019, with both burn treatment and year as independent variables. To measure the effect of time on these understory metrics in the absence of fire, we ran one-way ANOVAs on understory data from unburned subplots only, investigating the same four dependent variables and using year as the independent variable. We further investigated all ANOVA models with significant main or interaction effects using Tukey HSD comparisons. We also estimated total site richness for each group using Chao richness estimates (Chao 1984).

\section{Results}

\section{Effects of burning on soil chemistry and overstory forest structure}

Prior to cutting and burn treatments, the overstory plots were populated by roughly equal proportions of maples (red maple (Acer rubrum L.), striped maple (Acer pensylvanicum L.), sugar maple (Acer saccharum Marshall)), birches (sweet birch (Betula lenta L.), yellow birch (Betula alleghaniensis Britton)), and hickories (mockernut hickory (Carya tomentosa Lam. Nutt.), pignut hickory (Carya glabra Mill. Sweet), shagbark hickory (Carya ovata Mill. K. Koch)) with a few ashes (white ash (Fraxinus americana L.)), oaks (black oak (Quercus velutina Lam.), northern red oak (Quercus rubra L.)), and pines (eastern white pine (Pinus strobus L.)) (Fig. 3a). Between 2006 and 2019, the number of trees in the mid- and overstory increased regardless of burn treatment, and unburned plots had more individuals than burned plots in both years (Fig. 3a). In both 2006 and 2019, sweet birch dominated unburned plots, while burned plots maintained a larger proportion of oak and hickory (Fig. 3a).

In 1996, pre-cutting and pre-burning, basal area was high while the distribution of DBH values was low and heavily right skewed (Fig. 3b, c). Both basal area $\left(\chi_{2}^{2}=\right.$ 15.11, $p=0.001)$ and DBH $\left(\chi_{2}^{2}=51.77, p<0.001\right)$ differed significantly by year, and burned plots in 2006 and 2019 had significantly higher mean DBH than unburned plots $\left(\chi_{1}^{2}=21.84, p<0.001\right)$. In both 2006 and 2019, the DBH distribution on unburned plots was heavily right skewed toward smaller stems, primarily due to ingrowth of sweet birch, while the burned plots showed a relatively normal DBH distribution (Fig. 3c). Though basal area did not differ significantly by burn treatment for years 2006 and 2019 combined $\left(\chi_{1}^{2}=1.41, p=0.235\right)$, in 2019 , mean percent canopy cover over unburned subplots $(X=91.16)$ was greater than that of burned subplots $(X=80.89)(p=0.041)$.
The MANOVA model showed no significant effect of burn treatment on the eight measures of soil nutrients and $\mathrm{pH}\left(F_{1}=1.73, p=0.242\right)$, with no significant univariate effect of burn treatment on any of these parameters (Fig. 4). F-tests revealed that the soil in burned treatment areas exhibited greater variance than that of unburned areas in the natural log of potassium $\left(F_{7,7}=4.98, p=0.050\right)$ and percent nitrogen $\left(F_{7,7}=4.62, p=0.061\right)$; these effects were marginally significant $(\alpha<0.100)$ (Fig. 4).

\section{Effects of burning on understory composition}

Rank abundance curves showed little variation between pre-unburned and pre-burned subplots (Additional file 3). The 1996 understory in both pre-burn and pre-unburned subplots was dominated by Canada mayflower (Maianthemum canadense Desf.), wild sarsaparilla (Aralia nudicaulis L.), and grape. The most abundant tree seedling species in 1996 included sweet birch, sugar maple, and white ash as well as hickories and northern red oak. Regardless of burn treatment, the 2006 and 2019 understories were dominated by Canada mayflower, which increased in dominance over time (Additional file 3). Post-cutting subplots also showed high abundance of grape, wild sarsaparilla, and bellwort (Uvularia L. spp.). Aside from these four taxa, burned subplots were dominated by goldenrod (Solidago L. spp.), blackberry (Rubus L. spp.), cinquefoil (Potentilla L. spp.), and yellow loosestrife (Lysimachia L. spp.), while unburned subplots were dominated by sweet birch, Virginia creeper (Parthenocissus quinquefolia L. Planch), white wood aster (Eurybia divaricata L. G.L. Nesom), and partridgeberry (Mitchella repens L.). Burn treatments appeared to impact evenness in both 2006 and 2019; the unburned subplots show a steep drop-off in abundance after Canada mayflower, while the burned subplots had additional species with relatively high abundance.

The PERMANOVA models indicated that understory composition varied significantly by burn treatment $\left(F_{1}=\right.$ $12.802, p<0.001)$ and by year $\left(F_{2}=10.123, p<0.001\right)$. NMDS results echoed this finding, as subplots clustered by burn treatment and year when plotted on the first two ordination axes (Fig. 5a). Standard deviations showed a clear separation between groups with the exception of 2006 burned and 2006 unburned, which overlapped slightly. Both year $\left(r^{2}=0.77, p<0.001\right)$ and burn treatment $\left(r^{2}=0.27, p<0.001\right)$ showed a significant correlation with vegetation data. The overlaid vector and centroids for year and burn treatment, respectively, suggested that the effect of year was largely captured on NMDS axis 1, while burn treatment differed on both axes (Fig. 5a).

NMDS results for the 2019 understory vegetation data indicated clear separation of subplots by burn treatment 


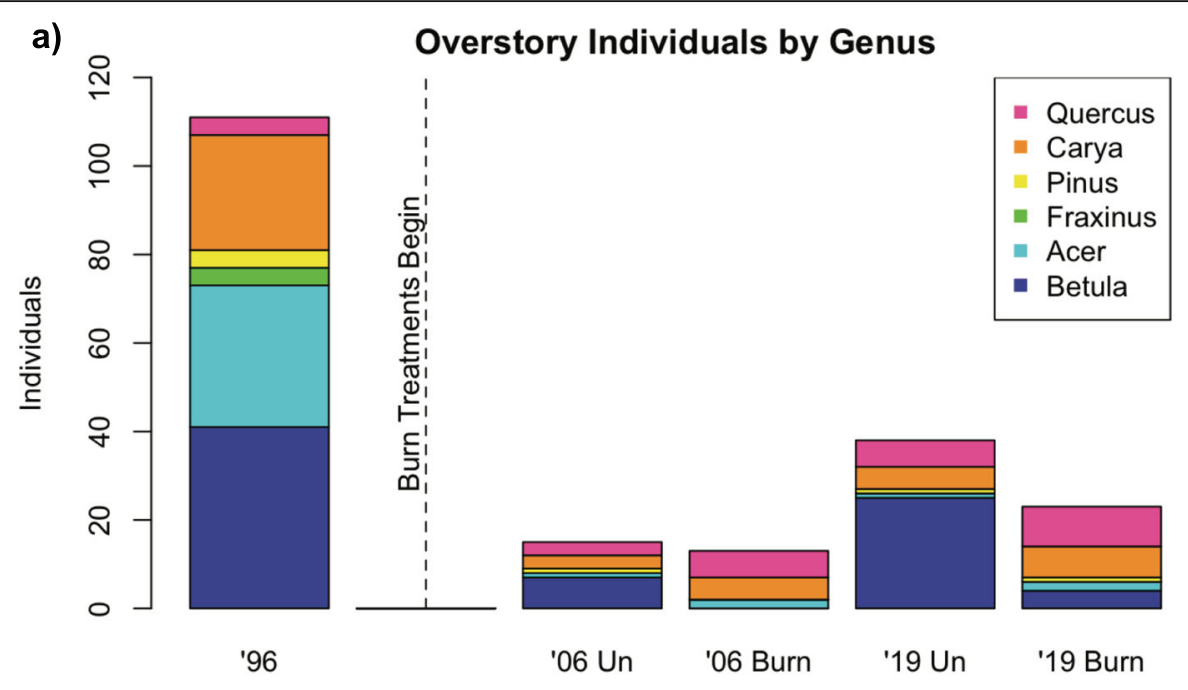

b)

Basal Area $^{\dagger}$

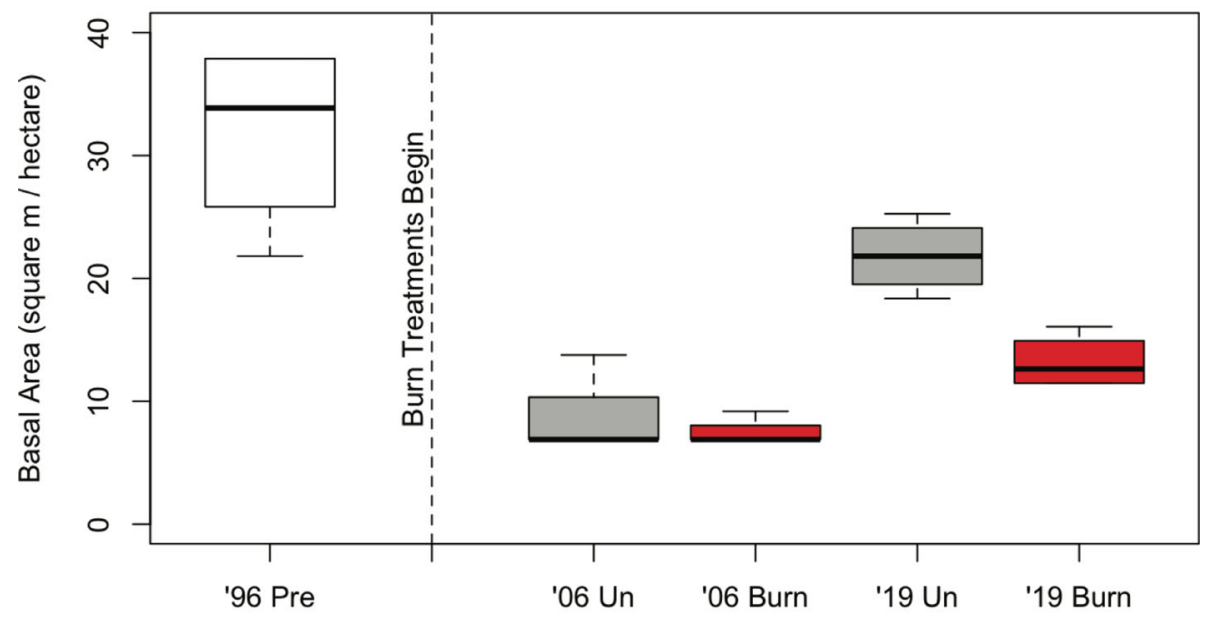

c)

$\mathrm{DBH}^{* \dagger}$

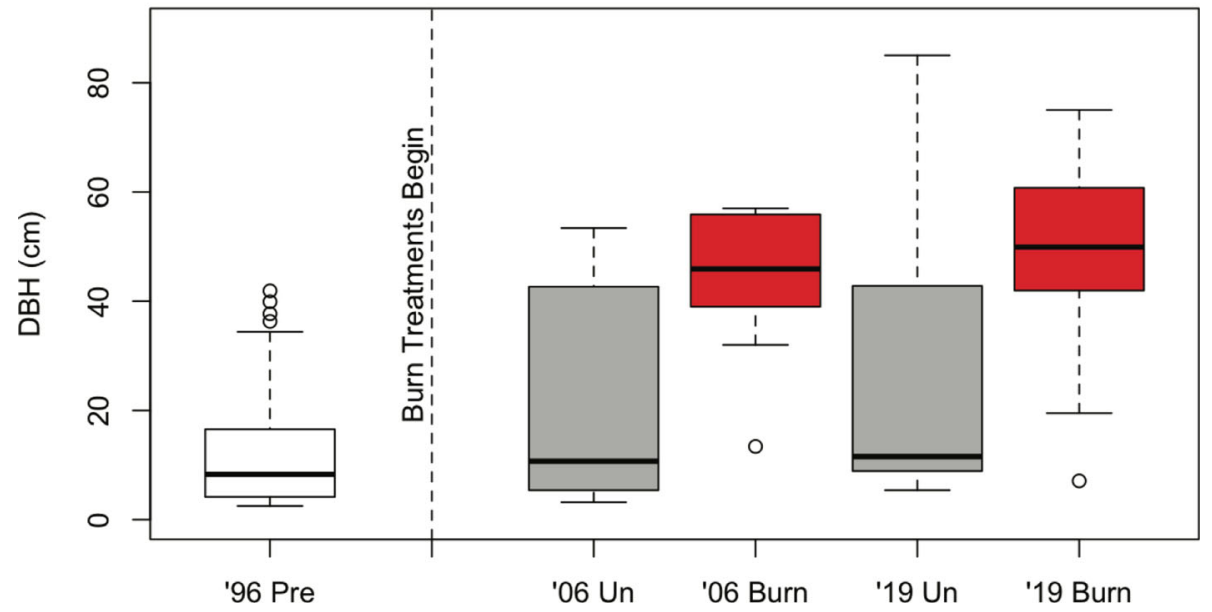

Fig. 3 (See legend on next page.) 
(See figure on previous page.)

Fig. 3 a Total number of overstory individuals by genus for 1996 pre-treatment plots and 2006 and 2019 burned and unburned plots. Relative frequency by species was as follows: Quercus: 75\% northern red oak, black oak, or hybrid; 18\% white oak (Quercus alba L.); 7\% scarlet oak (Quercus coccinea Münchh). Carya: 50\% shagbark hickory; 50\% pignut or mockernut hickory. Pinus: 100\% white pine. Fraxinus: 100\% white ash. Acer: $81 \%$ sugar maple; 16\% red maple; $3 \%$ striped maple. Betula: $98 \%$ sweet birch, $2 \%$ yellow birch. Boxplots depicting overstory b basal area and c DBH for 1996 pre-treatment plots and for 2006 and 2019 burned and unburned plots. The boxplot center line corresponds to the median, the box covers the interquartile range, and the whiskers extend to 1.5 times the interquartile range. Asterisk indicates a significant difference to $a=.05$ with respect to burn treatment using pooled 2006 and 2019 data (nonparametric Kruskal-Wallis ANOVA). Dagger symbol indicates a significant difference to $a=.05$ with respect to year (nonparametric Kruskal-Wallis ANOVA). Data were collected at the Yale-Myers Research and Demonstration Forest, Eastford, CT, USA

as well (Fig. 5b). Both percentage of canopy opening $\left(r^{2}\right.$ $=0.30, p=0.006)$ and burn treatment $\left(r^{2}=0.45, p<\right.$ $0.001)$ correlated with the vegetative composition. The overlaid environmental centroids and vector suggested greater canopy openings over burned subplots.

When taxa were plotted on these same two ordination axes, eight taxa were clustered within the polygon encompassing the burned subplots (roundlobe hepatica (Anemone americana DC. H. Hara), bedstraw (Galium
L. spp.), eastern poison ivy (Toxicodendron radicans $\mathrm{L}$. Kuntze), violet (Viola L. spp.), white ash, blackberry, hickory, yellow loosestrife), with seven additional taxa on the burned half of the ordination space but not overlapping the polygon encompassing the burned subplots (American hogpeanut (Amphicarpaea bracteata L. Fernald), Jack in the pulpit (Arisaema triphyllum L. Schott), Virginia strawberry (Fragaria virginiana Duchesne), common cinquefoil (Potentilla simplex Michx.),
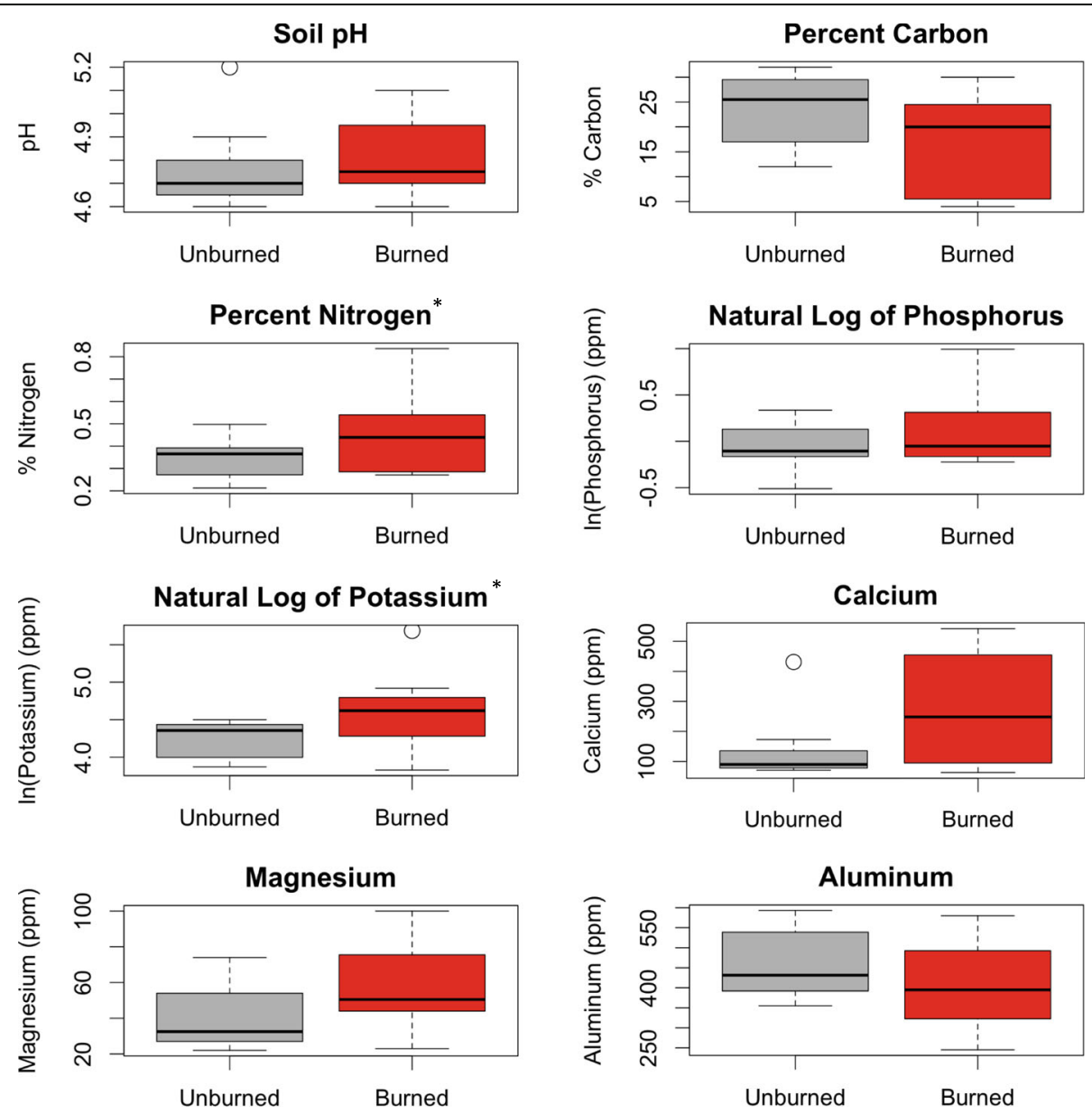

Fig. 4 Boxplots comparing pH, percent carbon and nitrogen, the natural log of phosphorus and potassium concentrations, and concentrations of calcium, magnesium, and aluminum in the top horizon of 2019 soil cores by burn treatment. The boxplot center line corresponds to the median, the box covers the interquartile range, and the whiskers extend to 1.5 times the interquartile range. Asterisk indicates marginally significant F-test $(a<0.100)$. Soil cores were collected at the Yale-Myers Research and Demonstration Forest, Eastford, CT, USA 


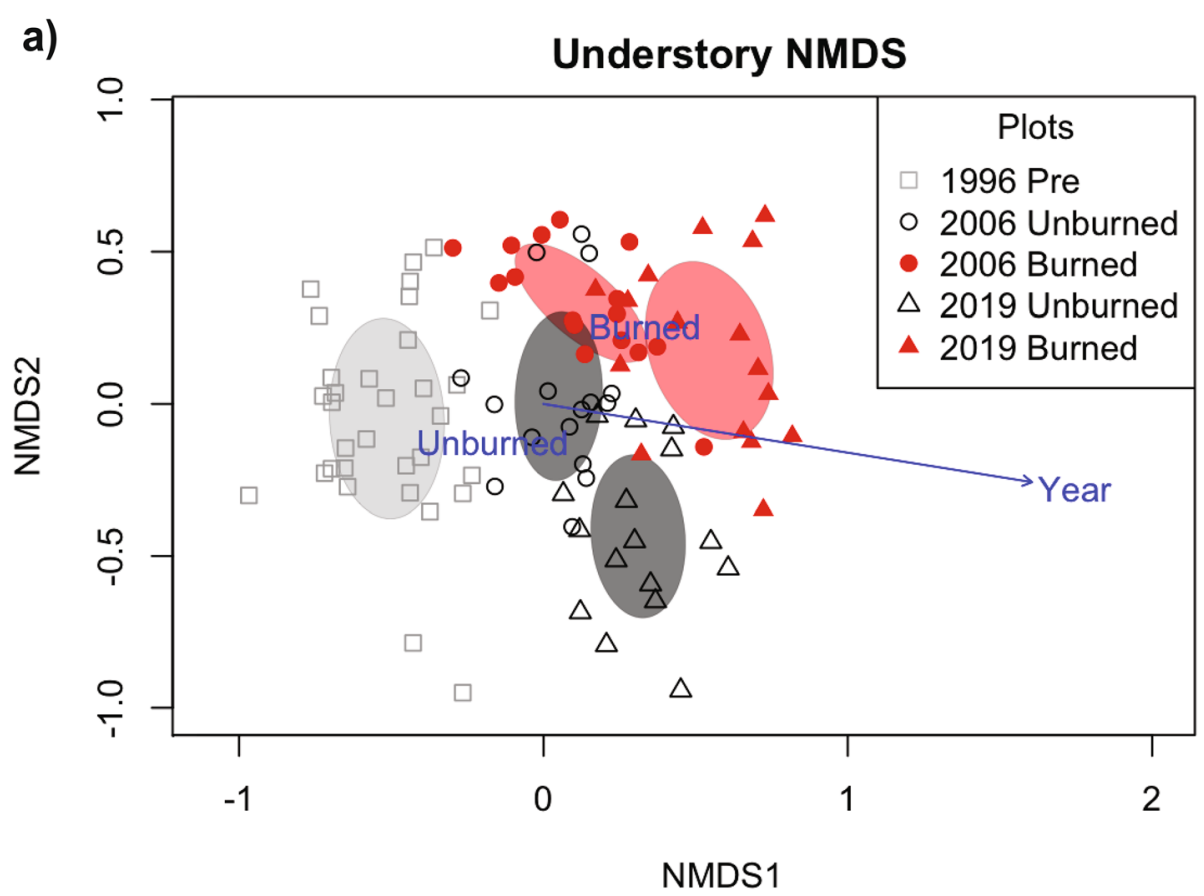

b) 2019 NMDS

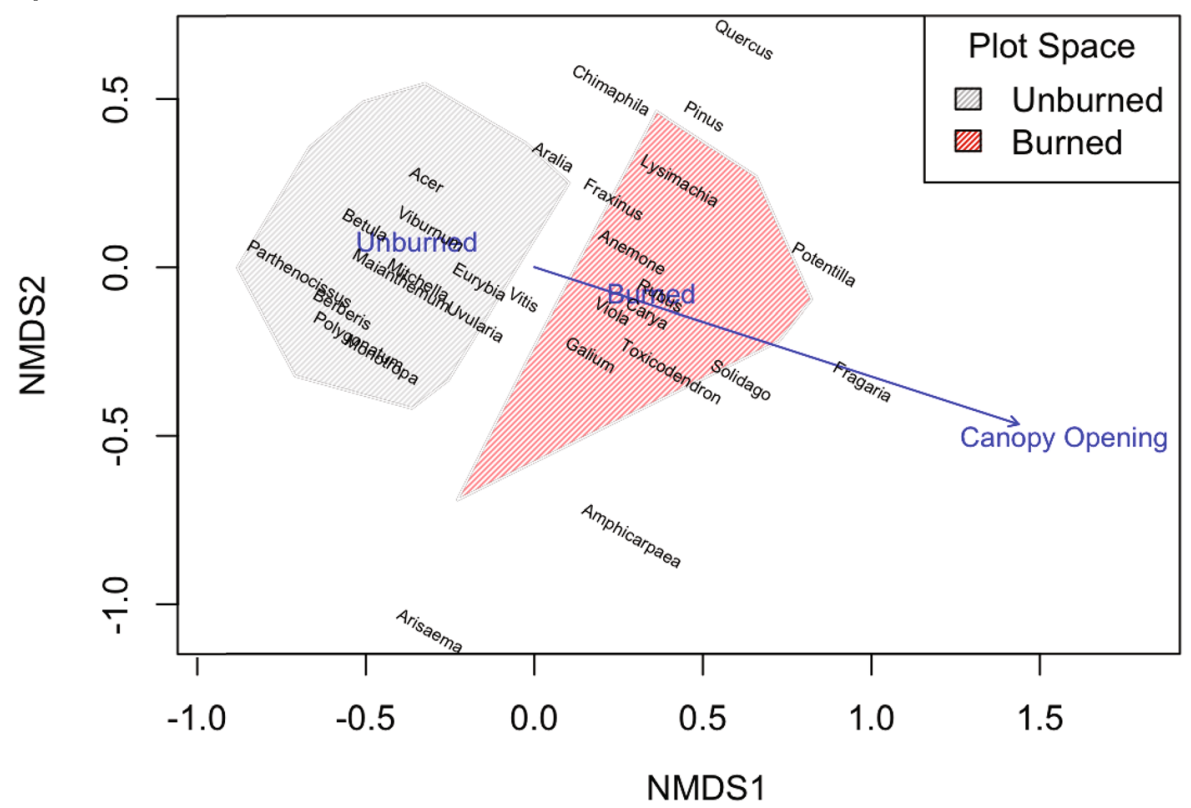

Fig. 5 a Biplots of understory subplot scores for the first two axes of non-metric multidimensional scaling. Shape of points indicates year and fill indicates burn treatment. Significant environmental variables are overlaid as vectors or centroids. Ellipses represent the standard deviation for all plots in a given year x burn treatment group. b Biplot of 2019 understory genera scores for the first two axes of non-metric multidimensional scaling, with labels representing the location of each genus. Nomenclature according to USDA PLANTS database (USDA NCRS 2020). Shaded polygons indicate the space encompassing all subplots in a given burn treatment group, with color indicating burn treatment. Significant environmental variables are overlaid as vectors or centroids. Understory data were collected at the Yale-Myers Research and Demonstration Forest, Eastford, CT, USA

goldenrod, oak, eastern white pine) (Fig. 5b). Eleven taxa fell within the space encompassed by unburned subplots (white wood aster, Japanese barberry (Berberis thunbergii
DC.), Virginia creeper, Indianpipe (Monotropa uniflora L.), Canada mayflower, partridgeberry, hairy Solomon's seal (Polygonatum pubescens Willd. Pursh.), mapleleaf 
viburnum (Viburnum acerifolium L.), bellwort, sweet birch, maple) and a twelfth fell nearby (wild sarsaparilla), while two genera occupied the intermediate space between the two groups (striped prince's pine (Chimaphila maculata L. Pursh), grape).

\section{Effects of burning on understory density, richness, diversity, and evenness}

A two-way ANOVA showed that burned subplots exhibited significantly greater plant density than unburned subplots, though Tukey HSD comparisons found a significant difference only for $2019(p=0.036)$ (Table 1 , Fig. 6a). On unburned subplots, density differed significantly by year $\left(F_{2}=17.54, p<0.001\right)$, with 1996 being significantly lower than $2006(p<0.001)$ and $2019(p<$ 0.001). Another two-way ANOVA and subsequent Tukey HSD comparisons revealed that species richness was greater on burned $\left(X=21\right.$ species per $\left.4 \mathrm{~m}^{2}\right)$ as compared to unburned $\left(X=16\right.$ species per $\left.4 \mathrm{~m}^{2}\right)$ subplots overall and in $2019(p<0.001)$, but not in 2006 (Table 1 , Fig. 6b). The two-way ANOVA also revealed a significant interaction effect of burn treatment and year: while richness on burned subplots did not change significantly over time, richness decreased significantly on unburned subplots from 2006 to 2019 ( $p=0.025$ ) (Table 1, Fig. $6 \mathrm{~b})$. This finding reflects the high level of species richness in 2006; when combining burned and unburned subplots, mean number of species per $4 \mathrm{~m}^{2}$ and Chao richness estimate peaked in 2006 (Additional file 4). However, the one-way ANOVA on unburned subplots across all three years showed no significant effect of year on species richness $\left(F_{2}=84.02, p=0.063\right)$.
Two-way ANOVAs showed a significantly greater diversity and evenness on burned subplots than on unburned plots, a trend that held overall and within a given year (Table 1, Fig. 6c, d). One-way ANOVA's on unburned subplots showed a significant effect of year on both diversity $\left(F_{2}=6.167, p=0.004\right)$ and evenness $\left(F_{2}=\right.$ $11.51, p<0.001)$. Though Shannon diversity on unburned subplots decreased over time (Fig. 6c), pairwise comparisons found differences only between the 1996 and 2019 subplots $(p=0.003)$. Similarly, evenness decreased over time on unburned subplots (Fig. 6d), and pairwise comparisons of evenness found differences between 1996 and $2006(p=0.003)$ and between 1996 and $2019(p<0.001)$.

\section{Discussion}

Effects of burning on soil chemistry and overstory forest structure

Overstory compositional differences between burned and unburned plots were roughly consistent with expectations put forth by Nowacki and Abrams' (2008) theory of mesophication and demonstrated by increases in oaks in a 15-year burn study by Oakman et al. (2019). Burned plots saw greater increases in the relative abundance of fire-adapted species such as oaks and hickories, while unburned plots were dominated by sweet birch. Maples, considered highly fire-sensitive, mesophytic, and gap opportunistic, varied little in the overstory by burn treatment and failed to return to the midstory after removal in 1996 (Nowacki and Abrams 2008; Chapman and McEwan 2016).

The changes in mid- and overstory basal area and DBH over time reflect the direct effects of overstory

Table 1 Two-way ANOVA results for the effects of burn treatment (burned or unburned) and year (2006 or 2019) on In(density), species richness, Shannon diversity, and Pielou's evenness calculated by subplot using understory data collected after burn treatments began (i.e., in 2006 and 2019) from the Yale-Myers Research and Demonstration Forest, Eastford, CT, USA. Items significant to $a=.05$ are in bold

\begin{tabular}{|c|c|c|c|c|}
\hline Dependent variable & Independent variable & df & $F$ value & $p$ value \\
\hline \multirow[t]{3}{*}{ Natural log of density } & Burn treatment & 1 & 8.71 & $0.005^{* *}$ \\
\hline & Year & 1 & 0.54 & 0.465 \\
\hline & Burn treatment $x$ year & 1 & 0.95 & 0.333 \\
\hline \multirow[t]{3}{*}{ Species richness (S) } & Burn treatment & 1 & 18.64 & $6.02 \mathrm{e}-05^{* * *}$ \\
\hline & Year & 1 & 0.67 & 0.416 \\
\hline & Burn treatment $x$ year & 1 & 10.90 & $0.002^{* *}$ \\
\hline \multirow[t]{3}{*}{ Shannon diversity $\left(\mathrm{H}^{\prime}\right)$} & Burn treatment & 1 & 37.97 & $6.59 \mathrm{e}-08^{* * *}$ \\
\hline & Year & 1 & 0.92 & 0.343 \\
\hline & Burn treatment $x$ year & 1 & 3.09 & 0.084 \\
\hline \multirow[t]{3}{*}{ Pielou's evenness ( $\left(J^{\prime}\right)$} & Burn treatment & 1 & 23.53 & $9.10 \mathrm{e}-06^{* * *}$ \\
\hline & Year & 1 & 0.57 & 0.452 \\
\hline & Burn treatment $x$ year & 1 & 0.20 & 0.658 \\
\hline
\end{tabular}

Significance levels: ${ }^{*}<.05 * *<.01 * * * .001$ 


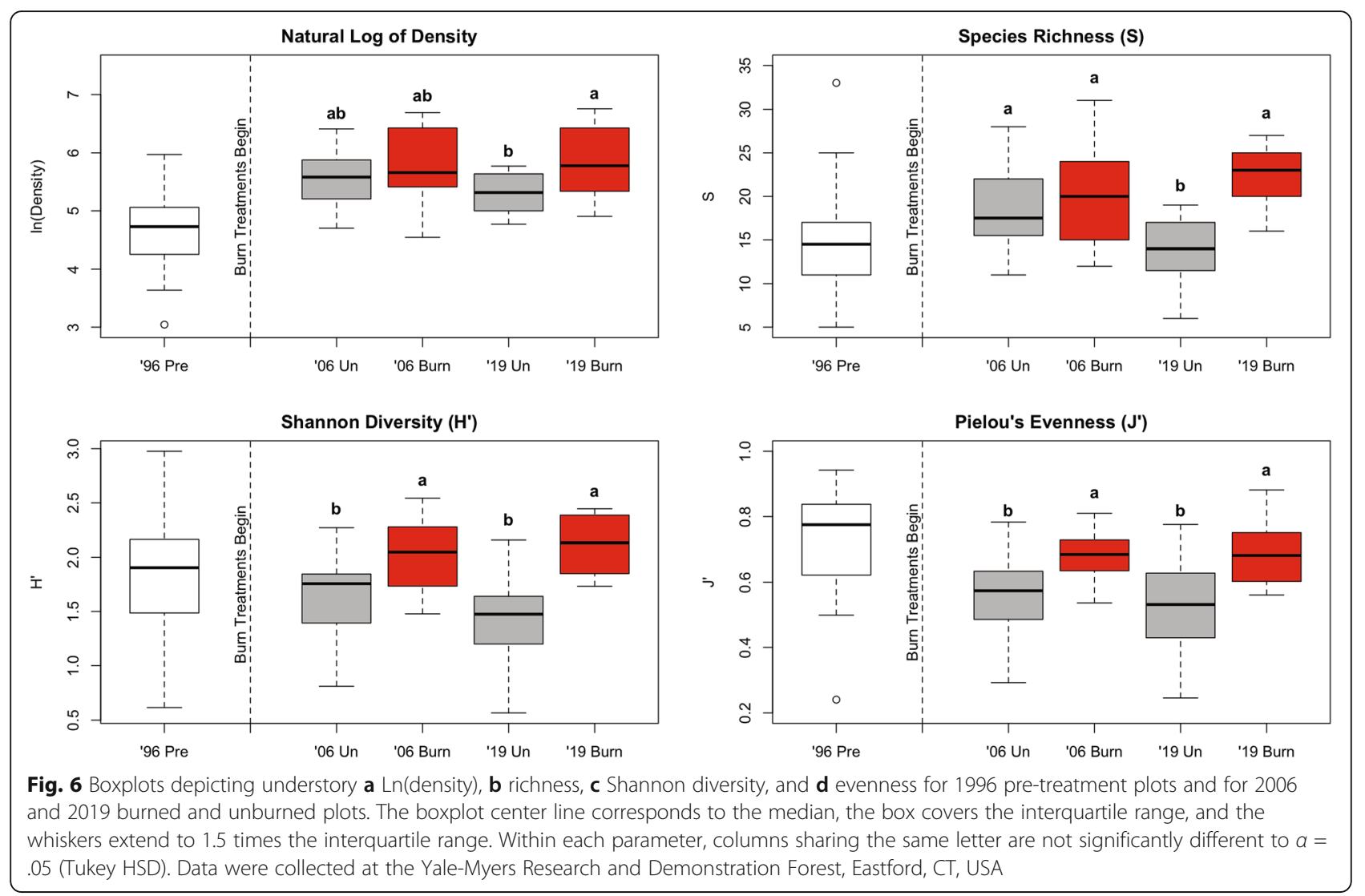

cutting and burning. Between 2006 and 2019, both the number of individuals (Fig. 3a) and basal area (Fig. 3b) increased more rapidly on unburned plots than on burned plots due to the ingrowth of a sapling layer that developed and persisted on unburned plots but never established as seedlings because of fire on burned plots. The heavily right-skewed distribution of DBH on unburned plots supports this explanation, showing that birch recruitment established almost immediately after the cutting treatment and incrementally increased over time to represent that majority of the sapling and pole size class. The absence of birch recruitment on burned plots is consistent with literature showing the low capacity of sweet birch to resprout after being topkilled by fire as compared to fire-adapted species such as hickories and oaks (Ward and Brose 2004). Three studies on the short-term effects of repeated, frequent prescribed burns (two to three burns within 3 to 5 years) found that mortality and density reduction occurred largely in the sapling layer (Arthur et al. 1998; Hutchinson and Sutherland 2000; Kinkead et al. 2013). However, for a very different forest type adjacent the prairies and dominated by burr oak (Quercus macrocarpa Michx.), Peterson and Reich (2001) suggest that frequent burning (three or more fires per decade) is required to remove the sapling layer, whereas a low frequency burn pattern that more closely emulates our study resulted in a dense sapling layer.

The difference in basal area between burned and unburned plots, which represents both the incremental growth of established birch in the unburned plots and the failure on burned plots to establish birch of sufficient size to endure fire between prescribed burn intervals, is more pronounced in 2019 than in 2006, despite the fact that the 2006 data were collected immediately after a burn while the 2019 data were collected 7 years after the most recent burn. This finding suggests two things: first is that the impact of burns on midstory structure persists for at least 6 to 7 years. Ducey et al. (1996) reached a similar conclusion, showing that the reduction of overstory basal area and density following a single prescribed burn persisted 8 years after the burn. It also suggests that the cumulative number of burns has a greater effect on midstory structure than time between burns, though more frequent sampling would be needed to support this conclusion.

As a whole, these results raise questions about the means by which changes to the forest structure affect the understory composition. Existing literature has focused on light availability as the means by which fireinduced changes to the overstory drive changes in resulting understory composition and abundance 
(Vander Yacht et al. 2017). For example, Lettow et al. (2014) found that a combination of mechanical thinning and burning increased understory light availability. Our 2019 densiometer data support this finding, showing significantly lower canopy cover over burned subplots, even though the overall canopy coverage values are high regardless of burn treatment due to the large size and expansive crowns of the overstory trees. This finding suggests that repeated prescribed burns are a potential mechanism to create greater light penetration, a legacy that can be maintained for over two decades following an initial cutting event. We suggest that the added midstory of black birch in the unburned areas affects groundstory shading, even though the absolute difference in canopy coverage between unburned and burned subplots is small.

Consistent with expectations from the literature, burning caused no lasting differences in the eight measured soil properties, suggesting that observed floristic differences are largely due to fire-induced changes to forest structure and composition rather than to bottom-up drivers such as nutrient availability (Certini 2005; Ganzlin et al. 2016). Burning resulted in greater site micro-heterogeneity in nitrogen and potassium. The elevated variance in nutrient levels from plot to plot could be indicative of uneven burn severity across the site. Gundale et al. (2005) found that variation in nitrogen cycling rates across sites was closely associated with variation in fine fuel consumed during prescribed burns. The greater variation in nitrogen across burned areas is a potential driver of increased vegetative diversity, as previous studies have found that increased heterogeneity of total inorganic nitrogen is associated with understory diversity (Gundale et al. 2005; Ganzlin et al. 2016).

\section{Effects of burning on understory composition}

The 1996 understory, surveyed prior to cutting and burn treatments, contained high densities of woody seedlings that would be termed advance regeneration and that roughly reflect the overstory composition (Ashton and Kelty 2018). In subsequent years of increased light, regardless of burn treatment, the top ten most abundant species shifted from woody seedlings to forbs and woody shrubs, consistent with expectations from Davison and Forman (1982) and Small and McCarthy (2002). Canada mayflower dramatically outstripped almost all other species in abundance on both burned and unburned subplots, perhaps due to its clonal growth habit and its adaptability to changes in light associated with thinning and spacing the forest canopy (USDA Forest Service 2008; Ellum 2009). Bellwort appeared in the top ten most abundant species on all four groups of subplots after 1996; this was likely a response to cutting as well, as Ruben et al. (1999) found that sessileleaf bellwort
(Uvularia sessilifolia L.) attained a higher density at the edges of clear-cuts.

Rank abundance plots suggest that repeated burn treatments and the accompanying reduction in canopy cover caused a major shift towards shade-intolerant, fire-enhanced herbs such as goldenrod and cinquefoil, both of which have been shown to be pioneers that increase following fire and other disturbances (Davison and Forman 1982; USDA Forest Service 2008; Holzmueller et al. 2009). Nearly all of the herbs in the ten most abundant taxa on burned subplots (with the exception of American hogpeanut) have a rhizome (Native Plant Trust 2020). The presence of a rhizome is a potential mechanism for enhancement following fire, as the underground rhizomes have been shown to survive low intensity burns, and the subsequent reduction in leaf litter from fire increases light penetration and thereby prompts seed germination and rhizome sprouting (Brown and Smith 2000). Unburned subplots were heavily populated by shade-tolerant species such as Virginia creeper, white wood aster, and partridgeberry (USDA Forest Service 2008). While woody seedlings disappeared from the top ten on burned subplots, sweet birch and striped maple remained abundant on unburned subplots, evidence of the shift towards the mesophytic composition predicted by Nowacki and Abrams (2008) and Holzmueller et al. (2009).

Multivariate analysis similarly indicated a significant shift in understory composition at the subplot level over time. The observation that the accompanying divergence by burn treatment increases over time reinforces the need for repeated burns to achieve lasting shifts in composition (Dey and Fan 2009). Blackberry, well established as a shade-intolerant "fire follower" due to increased seed bank germination following leaf litter reduction, is the dominant woody shrub on burned subplots and associates closely with the burned centroid in NMDS analysis of the 2019 understory (Davison and Forman 1982; Ashton et al. 1998; USDA Forest Service 2008). The distribution of birch and maple (unburned subplots) and hickory and pine (burned subplots) on 2019 ordination axes largely reinforces these compositional trends. Though oak is distant from both the burned and unburned centroids, raw data from the 2019 understory indicates that oak seedlings were more abundant on burned (21 individuals) than unburned (8 individuals) subplots, consistent with literature expectations (Nowacki and Abrams 2008; Oakman et al. 2019). The repeated but infrequent burning appeared to favor hickory establishment more strongly than oak, with higher numbers on burned (108 seedlings) as compared to unburned (28 seedlings) subplots. This may be why some older stands in this forest comprise almost exclusively hickory in the overstory, having established on brushy 
old fields after repeated fires in the early 1900s (personal observation; Lefland et al. 2018). Unsurprisingly, Indianpipe, a mycotrophic understory plant that lacks chlorophyll and derives all energy from fungal associations, showed an association with unburned subplots and high shade in ordination analysis (Native Plant Trust 2020).

\section{Effects of burning on understory density, richness, diversity, and evenness}

Consistent with previous studies, burning resulted in significantly higher understory plant density (Ducey et al. 1996; Arthur et al. 1998; Kinkead et al. 2013; Lettow et al. 2014; Knapp et al. 2015). However, the relative importance of cutting as compared to burning on understory density is unclear: Lettow et al. (2014) found a greater increase in density from cutting and burning than burning alone, Oakman et al. (2019) observed an increase in understory shrub cover from mechanical thinning but not burn treatments, and Kinkead et al. (2013) found that fire, not cutting, was the primary driver of increases in abundance.

Changes in richness showed complex temporal dynamics in response to the initial overstory thinning and spacing done in 1996. Chao richness estimates (Additional file 4) and unburned subplot-level richness (Fig. 6b) exhibited trends consistent with the Intermediate Disturbance Hypothesis in response to 1996 overstory cutting, increasing to a peak in 2006 and then declining by 2019. The Intermediate Disturbance Hypothesis suggests that richness is maximized at an intermediate time point following disturbance, when recolonization is sufficiently high and before competitive exclusion reduces the number of species (Connell 1978; Huston 1979; Palmer 1994). This pattern mirrors changes in understory light exposure following the 1996 thinning; the short-term spike in richness corresponds with increased understory light penetration, while the ensuing richness decline indicates an increase in shading over time, an effect that is more pronounced on unburned subplots due to the observed ingrowth of saplings. The importance of understory light exposure is supported by Duguid et al. (2013), who observed similar results in understory richness following the creation of experimental gaps on mesic and mid-slope sites. Baker and Hodges (1998) found a similar peak in woody diversity 10 to 15 years following a clear-cut harvest, and Howard and Lee (2003) concluded that woody and herbaceous species richness steadily declined over successional time from field to transition hardwood forest following a richness peak 14-44 years after abandonment. However, a greater sampling frequency at our site and across the northern oak-hickory region is needed to verify this trend.
The effect of burn treatments on richness was consistently positive within years but showed varied temporal dynamics. On average, burned subplots had a greater number of species than unburned subplots, consistent with expectations from the literature (Hutchinson and Sutherland 2000; Hutchinson et al. 2005; CavenderBares and Reich 2012; Lettow et al. 2014; Knapp et al. 2015). The difference in subplot-level richness by burn treatment increased as time went on, suggesting that richness increases with a greater number of prescribed burns, as observed by Arthur et al. (1998). However, Chao estimates of overall richness broken down by burn treatment show a post-burn spike in richness in 2006 that declines slightly by 2019 . Taken together, this suggests that between 2006 and 2019, repeated prescribed burns continue to reduce the dominance of fire-sensitive saplings and increase microsite heterogeneity, resulting in greater richness within a given burned subplot, even though the total number of species across the site remains steady or even declines slightly.

Consistent with prior burn studies on oak hickory sites, burning resulted in significantly greater diversity and evenness (Lettow et al. 2014; Knapp et al. 2015). Contrary to Small and McCarthy's (2002) study, which found that clear-cutting without fire resulted in greater Shannon diversity, diversity and evenness decreased over time on unburned subplots. Taken together, this suggests that prescribed burning is an effective means of maintaining diversity and evenness that would otherwise decline following overstory cutting.

There are several explanations for the increased understory density, richness, diversity, and evenness following fires. Our data indicate that canopy cover was lower over burned subplots, allowing for greater light availability for the understory that could result in higher understory density (Knapp et al. 2015). Ellum (2009) suggests that richness shows patterns of fluctuation over the course of forest succession, with periods of greater richness during stand initiation and understory reinitiation. Under this model, periodic burns that keep the tree regeneration in the stand initiation phase would maintain a high level of species richness, while unburned sections of the forest would experience a decrease in richness during the stem exclusion stage (Ellum 2009).

The increase in diversity and richness following fire makes sense from an evolutionary perspective as well (Nowacki and Abrams 2008). The millennia of periodic surface burns in New England promoted the dominance of fire-resistant, heliophilic species and constrained the dominance of fire-sensitive species. These fire-sensitive species have grown more abundant only in the last century of fire exclusion. The reintroduction of burns shifts the ecological conditions to favor the pool of fireresistant species, thereby allowing for greater richness 
and diversity post-burn (Trabaud and Lepart 1980). This explanation is supported by a 40 -year repeated burn study by Cavender-Bares and Reich (2012), which found that phylogenetic species variance was lowest on unburned plots, suggesting that burning yields a species composition that is higher in phylogenetic variation. The periodic nature of our burn treatments has also allowed for the co-existence of species along the gradient from fire-sensitive to fire-adapted, which contributes to the high levels of richness and diversity on burned subplots (Trabaud and Lepart 1980; Ryan et al. 2013; McCord et al. 2014).

\section{Conclusions}

This study sheds light on the long-term vegetative response of an oak-hickory forest to a thinning and spacing treatment of the overstory followed by periodic burning. It also highlights several potential mechanisms by which these disturbances regulate understory structure and composition. NMDS analysis suggests that differences in canopy cover between burned and unburned subplots exert control on understory density and composition, with increased light penetration due to midstory mortality on burned plots leading to a shift towards shade-intolerant herbs. Greater site-level microheterogeneity in nitrogen and potassium on burned plots constitutes a potential bottom-up driver of increased understory diversity following burns. By reinstituting a fire regime that more closely resembles that in which these forests evolved for thousands of years, this study also presents a potential means to restore presettlement, pyrogenic vegetation patterns to the New England landscape.

\section{Supplementary Information}

The online version contains supplementary material available at https://doi. org/10.1186/s42408-021-00115-2.

Additional file 1. T-tests comparing means of understory $\ln ($ density), richness, diversity, and evenness between 1996 plots to be burned and 1996 plots to remain unburned. Data were collected at the Yale-Myers Research and Demonstration Forest, Eastford, CT, USA.

Additional file 2. Shapiro-Wilk tests of normality for understory $\ln$ (density), richness, diversity, and evenness. Data were collected at the YaleMyers Research and Demonstration Forest, Eastford, CT, USA.

Additional file 3. Rank abundance curves of herbaceous and woody understory for each year of data collection, separated by burn treatment. The top ten most abundant species in each plot are labeled. Data were collected at the Yale-Myers Research and Demonstration Forest, Eastford, CT, USA.

Additional file 4. Chao richness estimate by year $x$ burn treatment for understory data collected at the Yale-Myers Research and Demonstration Forest, Eastford, CT, USA.

\section{Acknowledgements}

First, we would like to acknowledge that this research took place on the original indigenous land of the Nipmuc. We also would like to thank the Yale Forests and its staff and supporters for allowing this research opportunity, providing the logistical support, and paying for some of the soil analysis and the UMASS Soil and Plant Nutrient Testing laboratory and the Yale Analytical and Stable Isotope Center for soil processing and analysis. And we thank colleagues in our lab for comments and advice during the analysis of data and for their contributions to data collection: D. Ellum, B. Frey, R. Goldman, E. Hawes, D. Kane, L. Ostrowsky, L. Rally, D. Woodbury, and L. Yocum.

\section{Authors' contributions}

CGB collected the 2019 data, ran the analyses, and wrote initial manuscript drafts and revisions. MSA conceived of the experimental treatment, collected the initial 1996 data, funded and supervised the collection of the 2006 data, and served to mentor the first author in writing, analysis, and revisions. MCD helped mentor the first author in writing, analysis, and revisions. All authors approved the final manuscript.

\section{Funding}

We thank the Trumbull College Richter Summer Fellowship, the Summer Environmental Fellowship, and the Trumbull College Mellon Research Grant for partially funding the field work conducted by Caroline Borden.

\section{Availability of data and materials}

The data used and analyzed in this study are available from the corresponding author on reasonable request.

\section{Declarations}

Ethics approval and consent to participate

Not applicable

\section{Consent for publication}

Not applicable

\section{Competing interests}

The authors declare that they have no competing interests.

\section{Author details}

${ }^{1}$ Department of Ecology \& Evolutionary Biology, Yale University, 165 Prospect St, New Haven, CT 06511, USA. ${ }^{2}$ The Forest School, Yale School of

Environment, Yale University, 195 Prospect St, New Haven, CT 06511, USA.

Received: 7 December 2020 Accepted: 7 June 2021

Published online: 28 September 2021

\section{References}

Abrams, M.D., and G.J. Nowacki. 2020. Native American imprint in palaeoecology. Nature Sustainability 3 (11): 896-897. https://doi.org/10.1038/s41893-0200578-6.

Anderson, R.C., and J.E. Schwegman. 1991. Twenty years of vegetational change on a southern Illinois barren. Natural Areas Journal 11: 100-107 http://www. naturalareas.org/docs/v11_2_91_pp100_107.pdf.

Arthur, M.A., R.D. Paratley, and B.A. Blankenship. 1998. Single and repeated fires affect survival and regeneration of woody and herbaceous species in an oakpine forest. The Journal of the Torrey Botanical Society 125 (3): 225-236. https://doi.org/10.2307/2997220.

Ashton, M.S., and M. Kelty. 2018. The Practice of Silviculture: Applied Forest Ecology. 10th ed. Chichester: John Wiley \& Sons Ltd..

Ashton, P.M.S., P.G. Harris, and R. Thadani. 1998. Soil seed bank dynamics in relation to topographic position of a mixed-deciduous forest in southern New England, USA. Forest Ecology and Management 111: 15-22. https://doi. org/10.1016/S0378-1127(98)00305-3.

Baker, J.C., and J.D. Hodges. 1998. Changes in woody stem species diversity over time following clearcutting in the Mississippi river floodplain. In Proceedings of the Ninth Biennial Southern Silvicultural Research Conference: Clemson, South Carolina, February 25-27, 468-473. Asheville, North Carolina: USDA Forest Service, Southern Research Station.

Boerner, R.E.J., J. Huang, and S.C. Hart. 2009. Impacts of Fire and Fire Surrogate treatments on forest soil properties: a meta-analytical approach. Ecological Applications 19 (2): 338-358. https://doi.org/10.1890/07-1767.1.

Brose, P., T. Schuler, D. van Lear, and J. Berst. 2001. Bringing fire back: the changing regimes of the appalachian mixed-oak forests. Journal of 
Forestry 99: 30-35 https://academic.oup.com/jof/article/99/11/30/4614301 ?login=true.

Brose, P.H., D.C. Dey, and T.A. Waldrop. 2014. The fire-oak literature of eastern North America: synthesis and guidelines. General Technical Report NRS-135. Newtown Square: U.S. Department of Agriculture, Forest Service, Northern Research Station. https://doi.org/10.2737/NRS-GTR-135.

Brown, J.K., and J.K. Smith. 2000. Wildland fire in ecosystems: effects of fire on flora. General Technical Report RMRS-GTR-42-vol. 2. Ogden: U.S. Department of Agriculture, Forest Service, Rocky Mountain Research Station. https://doi. org/10.2737/RMRS-GTR-42-V2

Cavender-Bares, J., and P.B. Reich. 2012. Shocks to the system: community assembly of the oak savanna in a 40-year fire frequency experiment. Ecology 93 (sp8): S52-S69. https://doi.org/10.1890/11-0502.1.

Certini, G. 2005. Effects of fire on properties of forest soils: a review. Oecologia 143 (1): 1-10. https://doi.org/10.1007/s00442-004-1788-8

Chao, A. 1984. Nonparametric estimation of the number of classes in a population. Scandinavian Journal of Statistics 11: 265-270 https://www.jstor. org/stable/4615964

Chapin, F.S., P.M. Vitousek, and K. Van Cleve. 1986. The nature of nutrient limitation in plant communities. The American Naturalist 127 (1): 48-58. https://doi.org/10.1086/284466.

Chapman, J.I., and R.W. McEwan. 2016. Thirty years of compositional change in an old-growth temperate forest: the role of topographic gradients in oakmaple dynamics. PLOS ONE 11 (7): e0160238. https://doi.org/10.1371/journal. pone 0160238

Cogbill, C.V., J. Burk, and G. Motzkin. 2002. The forests of presettlement New England, USA: spatial and compositional patterns based on town proprietor surveys. Journal of Biogeography 29 (10-11): 1279-1304. https://doi.org/10.1 046/j.1365-2699.2002.00757.x.

Connell, J.H. 1978. Diversity in tropical rain forests and coral reefs. Science 199 (4335): 1302-1310. https://doi.org/10.1126/science.199.4335.1302.

Core Team, R. 2019. R: A language and environment for statistical computing. Vienna: R Foundation for Statistical Computing https://www.R-project.org/.

Cronon, W. 2011. Changes in the Land: Indians, Colonists, and the Ecology of New England. New York: Farrar, Straus and Giroux.

Davison, S.E., and R.T.T. Forman. 1982. Herb and shrub dynamics in a mature oak forest: a thirty-year study. Bulletin of the Torrey Botanical Club 109 (1): 64-73. https://doi.org/10.2307/2484469.

DeSelm, H.R., and E.E.C. Clebsch. 1991. Response types to prescribed fire in oak forest understory. In Fire and the environment: ecological and cultural perspectives. General Technical Report SE-GTR-69, ed. Stephen C. Nodvin and Thomas A. Waldrop, 22-23. Asheville: USDA Forest Service, Southeastern Forest Experiment Station. https://doi.org/10.2737/SE-GTR-69.

Dey, D.C., and Z. Fan. 2009. A review of fire and oak regeneration and overstory recruitment. In Proceedings of the $3 \mathrm{rd}$ fire in eastern oak forests conference; Carbondale, IL, May 20-22, General Technical Report NRS-P-46, ed. Todd F. Hutchinson, 2-20. Newtown Square: U.S. Department of Agriculture, Forest Service, Northern Research Station https://www.fs.usda.gov/treesearch/ pubs $/ 17288$.

Ducey, M.J., W.K. Moser, and P.M.S. Ashton. 1996. Effect of fire intensity on understory composition and diversity in a Kalmia-dominated oak forest, New England, USA. Vegetatio 123 (1): 81-90. https://doi.org/10.1007/ BF00044890,

Duguid, M.C., B.R. Frey, D.S. Ellum, M. Kelty, and M.S. Ashton. 2013. The influence of ground disturbance and gap position on understory plant diversity in upland forests of southern New England. Forest Ecology and Management 303: 148-159. https://doi.org/10.1016/j.foreco.2013.04.018.

Elliott, KJ., R.L. Hendrick, A.E. Major, J.M. Vose, and W.T. Swank. 1999. Vegetation dynamics after a prescribed fire in the southern Appalachians. Forest Ecology and Management. 114 (2-3): 199-213. https://doi.org/10.1016/S0378-1127(98)00351-X.

Ellum, D.S. 2009. Floristic diversity in managed forests: demography and physiology of understory plants following disturbance in southern New England forests. Journal of Sustainable Forestry 28 (1-2): 132-151. https://doi. org/10.1080/10549810802626431.

Foster, D.R., S. Clayden, D.A. Orwig, B. Hall, and S. Barry. 2002. Oak, chestnut and fire: climatic and cultural controls of long-term forest dynamics in New England, USA. Journal of Biogeography 29 (10-11): 1359-1379. https://doi. org/10.1046/j.1365-2699.2002.00760.x.

Foster, D.R., G. Motzkin, and B. Slater. 1998. Land-use history as long-term broadscale disturbance: regional forest dynamics in central New England. Ecosystems 1 (1): 96-119. https://doi.org/10.1007/s100219900008.
Fralish, J.S. 2003. The Central Hardwood Forest: its boundaries and physiographic provinces. In General Technical Report NC-234. St. Paul: U.S. Department of Agriculture, Forest Service, North Central Research Station https://www.fs. usda.gov/treesearch/pubs/12317\#: :text=Geographically\%2C\%20the\%2 Oregion\%20is\%20also,Plain\%20extend\%20into\%20the\%20region.

Fuller, J.L., D.R. Foster, J.S. McLachlan, and N. Drake. 1998. Impact of human activity on regional forest composition and dynamics in central New England. Ecosystems 1 (1): 76-95. https://doi.org/10.1007/s100219900007.

Ganzlin, P.W., M.J. Gundale, R.E. Becknell, and C.C. Cleveland. 2016. Forest restoration treatments have subtle long-term effects on soil $\mathrm{C}$ and $\mathrm{N}$ cycling in mixed conifer forests. Ecological Applications 26 (5): 1503-1516. https://doi. org/10.1002/15-1100.

Gundale, M.J., T.H. DeLuca, C.E. Fiedler, P.W. Ramsey, M.G. Harrington, and J.E. Gannon. 2005. Restoration treatments in a Montana ponderosa pine forest: effects on soil physical, chemical and biological properties. Forest Ecology and Management 213 (1-3): 25-38. https://doi.org/10.1016/j.foreco.2005.03.015.

Guyette, R., M. Stambaugh, D. Dey, and R. Muzika. 2012. Predicting fire frequency with chemistry and climate. Ecosystems 15 (2): 322-335. https://doi.org/10.1 007/s10021-011-9512-0.

Hall, B., G. Motzkin, D.R. Foster, M. Syfert, and J. Burk. 2002. Three hundred years of forest and land-use change in Massachusetts, USA. Journal of Biogeography 29 (10-11): 1319-1335. https://doi.org/10.1046/j.1365-2699.2002. 00790.x.

Hart, J.L., and M.L. Buchanan. 2012. History of fire in eastern oak forests and implications for restoration. In Proceedings of the 4 th fire in eastern oak forests conference, Springfield, MO, May 17-19, General Technical Report NRS-P-102, ed. Daniel C. Dey, Michael C. Stambaugh, Stacy L. Clark, and Callie J. Schweitzer, 34-51. Newtown Square: U.S. Department of Agriculture, Forest Service, Northern Research Station https://www.fs.usda.gov/treesearch/ pubs/42130.

Holzmueller, E.J., S. Jose, and M.A. Jenkins. 2009. The response of understory species composition, diversity, and seedling regeneration to repeated burning in southern Appalachian oak-hickory forests. Natural Areas Journal 29 (3): 255-262. https://doi.org/10.3375/043.029.0305.

Howard, L.F., and T.D. Lee. 2003. Temporal patterns of vascular plant diversity in southeastern New Hampshire forests. Forest Ecology and Management 185: 5-20. https://doi.org/10.1016/S0378-1127(03)00243-3.

Huston, M. 1979. A general hypothesis of species diversity. The American Naturalist 113 (1): 81-101. https://www.jstor.org/stable/2459944. https://doi. org/10.1086/283366.

Hutchinson, T., and S. Sutherland. 2000. Fire and understory vegetation: a largescale study in Ohio and a search for general response patterns in central hardwood forests. In Proceedings: workshop on fire, people, and the central hardwoods landscape, Richmond, KY, March 12-14, General Technical Report NE-274, ed. D.A. Yaussy, 64-74. Newtown Square: U.S. Department of Agriculture, Forest Service, Northeastern Research Station. https://doi.org/10.2 737/NE-GTR-274.

Hutchinson, T.F., R.E.J. Boerner, S. Sutherland, E.K. Sutherland, and L.R. Iverson. 2005. Prescribed fire effects on the herbaceous layer of mixed-oak forests. Canadian Journal of Forest Research 35 (4): 877-890. https:/doi.org/10.1139/ x04-189.

Kindt, R., and R. Coe. 2005. Tree diversity analysis. A manual and software for common statistical methods for ecological and biodiversity studies. Nairobi: World Agroforestry Centre (ICRAF) ISBN 92-9059-179-X.

Kinkead, C.O., J.M. Kabrick, M.C. Stambaugh, and K.W. Grabner. 2013. Changes to oak woodland stand structure and ground flora composition caused by thinning and burning. In Proceedings of the 18th Central Hardwood forest conference, Morgantown, WW, March 26-28, General Technical Report NRS-P117, ed. G.W. Miller, T.M. Schuler, K.W. Gottschalk, J.R. Brooks, S.T. Grushecky, B.D. Spong, and J.S. Rentch, 373-383. Newtown Square: U.S. Department of Agriculture, Forest Service, Northern Research Station https://www.nrs.fs.fed. us/pubs/44102.

Knapp, B.O., K. Stephan, and J.A. Hubbart. 2015. Structure and composition of an oak-hickory forest after over 60 years of repeated prescribed burning in Missouri, U.S.A. Forest Ecology and Management 344: 95-109. https://doi.org/1 0.1016/.jforeco.2015.02.009.

Kreye, J.K., J.M. Varner, J.K. Hiers, and J. Mola. 2013. Toward a mechanism for eastern North American forest mesophication: differential litter drying across 17 species. Ecological Applications 23 (8): 1976-1986. https://doi.org/10.1890/13-0503.1.

Lefland, A.B., M.C. Duguid, R.S. Morin, and M.S. Ashton. 2018. The demographics and regeneration dynamic of hickory in second-growth temperate forest. 
Forest Ecology and Management 419: 187-196. https://doi.org/10.1016/j. foreco.2018.03.027.

Lettow, M.C., L.A. Brudvig, C.A. Bahlai, and D.A. Landis. 2014. Oak savanna management strategies and their differential effects on vegetative structure, understory light, and flowering forbs. Forest Ecology and Management 329: 89-98. https://doi.org/10.1016/j.foreco.2014.06.019.

Magurran, A.E. 1988. Ecological Diversity and its Measurement. Springer Netherlands. https://doi.org/10.1007/978-94-015-7358-0.

McCord, J.M., C.A. Harper, and C.H. Greenberg. 2014. Brood cover and food resources for wild turkeys following silvicultural treatments in mature upland hardwoods. Wildlife Society Bulletin 38 (2): 265-272. https://doi.org/10.1002/ wsb.403.

Native Plant Trust. 2020. Full key for plant identification. Go Botany https://gobota ny.nativeplanttrust.org/.

NOAA, National Centers for Environmental Information. 2020. Climate at a glance: statewide time series. August.

Nowacki, G.J., and M.D. Abrams. 2008. The demise of fire and "mesophication" of forests in the eastern United States. BioScience 58 (2): 123-138. https://doi. org/10.1641/B580207.

NRCS. 2008. Soil Survey of the State of Connecticut. In Cooperation with the Connecticut Agricultural Experiment Station. The Storrs Agricultural Experiment Station, and Connecticut Department of Environmental Protection.

Oakman, E.C., D.L. Hagan, T.A. Waldrop, and K. Barrett. 2019. Understory vegetation responses to 15 years of repeated fuel reduction treatments in the southern Appalachian Mountains, USA. Forests 10 (4): 350. https://doi. org/10.3390/f10040350

Oksanen, J., F.G. Blanchet, M. Friendly, R. Kindt, P. Legendre, D. McGlinn, P.R. Minchin, et al. 2019. vegan: Community Ecology Package. R package version 2.5-6. https://CRAN.R-project.org/package=vegan.

Palmer, M.W. 1994. Variation in species richness: towards a unification of hypotheses. Folia Geobotanica et Phytotaxonomica 29 (4): 511-530. https:// doi.org/10.1007/BF02883148

Parshall, T., and D.R. Foster. 2002. Fire on the New England landscape: regional and temporal variation, cultural and environmental controls. Journal of Biogeography 29 (10-11): 1305-1317. https://doi.org/10.1046/j.1365-2699.2002.00758.x.

Patterson, W.A. 2006. The paleoecology of fire and oaks in eastern forests. In Fire in eastern oak forests: delivering science to land managers, proceedings of a conference, Columbus, OH, November 15-17, General Technical Report NRS-P-1, ed. Matthew B. Dickinson, 2-19. Newtown Square: U.S. Department of Agriculture, Forest Service, Northern Research Station https://www.fs.usda. gov/treesearch/pubs/18429.

Patterson, W.A., and K.E. Sassaman. 1988. Indian fires in the prehistory of New England. In Holocene Human Ecology in Northeastern North America, Interdisciplinary Contributions to Archaeology, ed. George P. Nicholas, 107135. Boston: Springer. https://doi.org/10.1007/978-1-4899-2376-9_6.

Peterson, D.W., and P.B. Reich. 2001. Prescribed fire in oak savanna: fire frequency effects on stand structure and dynamics. Ecological Applications 11 (3): 914927. https://doi.org/10.1890/1051-0761(2001)011[0914:PFIOSF]2.0.CO;2.

Pielou, E.C. 1966. The measurement of diversity in different types of biological collections. Journal of Theoretical Biology 13: 131-144. https://doi.org/10.1016/ 0022-5193(66)90013-0.

Poulos, H. 2015. Fire in the Northeast: learning from the past, planning for the future. Journal of Sustainable Forestry 34 (1-2): 6-29. https://doi.org/10.1080/1 0549811.2014 .973608

Ruben, J.A., D.T. Bolger, D.R. Peart, and M.P. Ayres. 1999. Understory herb assemblages 25 and 60 years after clearcutting of a northern hardwood forest, USA. Biological Conservation 90: 203-215. https://doi.org/10.1016/ S0006-3207(99)00032-4

Ruffner, C.M. 2006. Understanding the evidence for historical fire across eastern forests. In Fire in eastern oak forests: delivering science to land managers; proceedings of a conference, Columbus, OH, November 15-17, General Technical Report NRS-P-1, ed. Matthew B. Dickinson, 40-48. Newtown Square: U.S. Department of Agriculture, Forest Service, Northern Research Station https://books.google.com/books?id=roZLAAAAYAAJ.

Ryan, K.C., E.E. Knapp, and J.M. Varner. 2013. Prescribed fire in North American forests and woodlands: history, current practice, and challenges. Frontiers in Ecology and the Environment 11 (s1): e15-e24. https://doi.org/10.1890/120329.

Small, C.J., and B.C. McCarthy. 2002. Spatial and temporal variation in the response of understory vegetation to disturbance in a central Appalachian oak forest. The Journal of the Torrey Botanical Society 129 (2): 136-153. https:// doi.org/10.2307/3088727.
Soil Survey Staff 1999. Soil taxonomy: A basic system of soil classification for making and interpreting soil surveys. Natural Resources Conservation Service. U.S. Department of Agriculture Handbook Number 436.

Stambaugh, M.C., J.M. Varner, R.F. Noss, D.C. Dey, N.L. Christensen, R.F. Baldwin, R. P. Guyette, B.B. Hanberry, C.A. Harper, S.G. Lindblom, and T.A. Waldrop. 2015. Clarifying the role of fire in the deciduous forests of eastern North America: reply to Matlack. Conservation Biology 29 (3): 942-946. https://doi.org/1 $0.1111 /$ cobi.12473.

Trabaud, L., and J. Lepart. 1980. Diversity and stability in garrigue ecosystems after fire. Vegetatio 43 (1-2): 49-57. https://doi.org/10.1007/BF00121017.

USDA Forest Service. 2008. Fire effects information system. Forest Service: U.S. Department of Agriculture https://www.feis-crs.org/feis/.

USDA NCRS. 2020. The PLANTS Database. https://plants.sc.egov.usda.gov/java/, Utah AGRC. 2020. US States. ArcGIS Hub.

Vander Yacht, A.L., S.A. Barrioz, P.D. Keyser, C.A. Harper, D.S. Buckley, D.A. Buehler, and R.D. Applegate. 2017. Vegetation response to canopy disturbance and season of burn during oak woodland and savanna restoration in Tennessee. Forest Ecology and Management 390: 187-202. https://doi.org/10.1016/j. foreco.2017.01.029.

Varner, J.M., M.A. Arthur, S.L. Clark, D.C. Dey, J.L. Hart, and C.J. Schweitzer. 2016. Fire in eastern North American oak ecosystems: filling the gaps. Fire Ecology 12 (2): 1-6. https://doi.org/10.4996/fireecology.1202001.

Ward, J.S., and P.H. Brose. 2004. Mortality, survival, and growth of individual stems after prescribed burning in recent hardwood clearcuts. In Proceedings of the 14th central hardwoods forest conference, Wooster, OH, March 16-19, General Technical Report NE-316, ed. D.A. Yaussy, D.M. Hix, R.P. Long, and P.C. Goebel, 193-199. Newtown Square: U.S. Department of Agriculture, Forest Service, Northeastern Forest Experiment Station. https://doi.org/10.2737/NEGTR-316.

Ward, J.S., and G.R. Stevens. 1989. Long-term effects of a 1932 surface fire on stand structure in a Connecticut mixed hardwood forest. In Proceedings of the 7th central hardwoods forest conference, Carbondale, IL, March 5-8, General Technical Report NC-132, ed. G. Rink and C.A. Budelsky, 267-273. St Paul: U.S. Department of Agriculture, Forest Service, North Central Forest Experiment Station. https://doi.org/10.2737/NC-GTR-132.

Yale School Forests. 2019. Mapping resources. Yale School Forests https://forests. yale.edu/management/mapping-resources.

\section{Publisher's Note}

Springer Nature remains neutral with regard to jurisdictional claims in published maps and institutional affiliations.

\section{Submit your manuscript to a SpringerOpen ${ }^{\circ}$ journal and benefit from:}

- Convenient online submission

- Rigorous peer review

- Open access: articles freely available online

- High visibility within the field

- Retaining the copyright to your article

Submit your next manuscript at $\boldsymbol{\nabla}$ springeropen.com 